\title{
Phosphorylation of gH2AX as a novel prognostic biomarker for laryngoesophageal dysfunction-free survival
}

\author{
María José de Miguel-Luken ${ }^{1}$, Manuel Chaves-Conde ${ }^{1}$, Begoña Quintana ${ }^{2}$, Alicia \\ Menoyo $^{3}$, Isabel Tirado ${ }^{3}$, Verónica de Miguel-Luken ${ }^{4}$, Jerónimo Pachón ${ }^{2}$, David \\ Chinchón ${ }^{5}$, Vladimir Suarez ${ }^{2}$ and Amancio Carnero ${ }^{6}$ \\ ${ }^{1}$ Department of Medical Oncology, Virgen del Rocío University Hospital, Seville, Spain \\ 2 Department of Radiation Oncology, Virgen del Rocío University Hospital, Seville, Spain \\ ${ }^{3}$ Department of Otorhinolaryngology, Virgen del Rocío University Hospital, Seville, Spain \\ ${ }^{4}$ University of Málaga, Málaga, Spain \\ ${ }^{5}$ Department of Pathology, Virgen del Rocío University Hospital, Seville, Spain \\ ${ }^{6}$ Instituto de Biomedicina de Sevilla, IBIS/Hospital Universitario Virgen del Rocío/ Universidad de Sevilla/ Consejo Superior \\ de Investigaciones Científicas, Seville, Spain
}

Correspondence to: Amancio Carnero, email: acarnero-ibis@us.es

Keywords: laryngeal cancer, H2AX, biomarker, laryngeal preservation, DDR, Pathology Section

Received: November 03, 2015 Accepted: April 22, $2016 \quad$ Published: May 04, 2016

\section{ABSTRACT}

Current larynx preservation treatments have achieved an improvement of laryngoesophageal dysfunction-free survival (LDS) but lead to significant toxicities and recurrences. At present, there is no evidence to select the group of patients that may benefit from preservation approaches instead of surgery. Therefore, laryngeal biomarkers could facilitate pretreatment identification of patients who could respond to chemoradiation-based therapy. In this study, we evaluated retrospectively 53 patients with larynx cancer to determine whether gH2AX phosphorylation (pH2AX) alone or in combination with the membrane protein MAP17 (PDZK1IP1) could be used as prognostic biomarkers. We also evaluated whether the completion of cisplatin treatment and radiotherapy could predict survival in combination with pH2AX.

We found that the dose of cisplatin received but not the length of the radiotherapy influenced LDS. High-pH2AX expression was associated with prolonged LDS (HR 0.26, $p=0.02)$ while MAP17 correlated with overall survival (OS) (HR 0.98, $p=0.05)$. High-MAP17 and high-pH2AX combined analysis showed improved LDS (with 61.35 months vs 32.2 months, $p=0.05$ ) and OS (with 66.6 months vs 39.8 months, $p=$ $0.01)$. Furthermore, the subgroup of high-pH2AX and optimal dose of cisplatin was also associated with OS ( 72 months vs 38.6 months, $p=0.03$ ) and LDS (66.9 months vs 27 months, $p=0.017$ ). These findings suggest that $\mathrm{pH} 2 \mathrm{AX}$ alone or better in combination with MAP17 may become a novel and valuable prognostic biomarker for patients with laryngeal carcinoma treated with preservation approaches.

\section{INTRODUCTION}

Squamous cell carcinoma of the head and neck represents $4 \%$ of all cancers diagnosed worldwide, with more than 500.000 new cases recorded in 2008 [1, 2]. Of them, $30 \%$ were laryngeal cancer with an estimated agestandardized world mortality rate of 2.3/100.000 habitants. Alcohol and tobacco abuse are common etiologic factors
[3] but exposure to hard-alloys dust, chlorinated solvents [4] and familiar genetic patterns [5] have been also implicated. The role of Human Papilomavirus (HPV) is well established for squamous cell carcinoma of the oropharynx but it remains unclear for laryngeal cancer [6]. Furthermore, these patients are at risk of developing second primary tumors due to chronic aerodigestive tract carcinogen exposure: $14 \%$ in 5 years, $26 \%$ in 10 years and 
$37 \%$ in 15 years [7]. The main prognostic factor for overall survival (OS) is tumor staging, where node invasion is more relevant than tumor extension [8]. Other OS prognostic factors are patient's comorbidity, performance status-ECOG (PS) [9], persistent toxic consumption habits [10], second primary tumor appearance [11] and primary tumor localization. In particular, glottic tumors have an $81 \%$ OS rate while supraglottic tumors drop to $70 \%$, probably due to early detection [12]. Disease-free survival prognostic factors include PS $[9,13]$, node invasion [13, 14], localization [9], pathologic stage (pT) [14], surgical resection margins [13] and pretreatment tracheotomy [15]. Moreover, T4 primary extension and more than $2 \mathrm{~cm}$ tumoral invasion of the base of the tongue were shown to be associated with increased salvage laryngectomy in the Veterans study [16].

Total laryngectomy was the gold standard treatment by the 1980s with subsequent loss of speech and airway patency [17]. Consequently, treatment aims changed in order to improve patient's quality of life through larynx sparing approaches. Currently, early stages (I and II) are treated with either surgery or radiotherapy (RT) as they have been accepted to have similar effectiveness. However, both treatments have not been compared in a randomized trial so far. Reported five-year OS is typically 70 to $90 \%[18,19]$. Advanced disease requires multimodal approach, usually a combination of chemotherapy (CT) or biotherapy (B) plus RT. Although functional organ sparing approaches permit larynx preservation, they do not provide a survival advantage over total laryngectomy [20]. Three sparing approaches are accepted: RT, bio or chemotherapy with concomitant radiotherapy (B/CT RT) and induction CT (ICT) followed by RT with or without $\mathrm{B} / \mathrm{CT}$.

CTRT with concurrent cisplatin showed higher preservation rates compared to other two arms with RT alone or induction cisplatin plus fluorouracil followed by RT ( $88 \%$ versus $-v s-70 \%$ and $75 \%$, respectively) with similar two and five year survival [21]. Later, a 10-year follow-up publication confirmed that the arms that included ICT improved laryngectomy-free survival (LFS). Contrary to preservation rates, LFS includes not just the need of salvage laryngectomy but also speech and swallowing quality. It is, therefore, more similar to what we currently understand as larynx preservation [22]. A subsequent meta-analysis for locally advanced larynx cancer found that adding CT concomitant with RT led to a benefit of $6.5 \%$ absolute improvement in 5-year OS [23].

The optimal dose of cisplatin during RT remains still unclear [24-26]. Two or three courses of threeweekly cisplatin could be considered the optimal dose for concurrent CTRT and equivalent doses of carboplatin have also been accepted by expert panels. However, preservation approaches entail up to a $43 \%$ rate of late toxicities [27] and have not shown to prolong OS more than surgery. Interestingly, 5-year OS was reported to drop from $67.4 \%$ in 1985 to $61.9 \%$ in 2007 (Source: Surveillance, Epidemiology and End Results Program. Accessed: http://seer.cancer.gov/). Nevertheless, these results do not allow making major conclusions, as preservation approaches were not broadly used until the time of database collection.

The high rate of toxicities and the non-improved survival with preservation approaches lead to the need for biomarker development. Predictive larynx biomarkers would facilitate pretreatment identification of those patients who are unlikely going to be cured by radiation-based therapy. By managing these patients with surgery rather than a preservation approach, local disease control and possibly survival could potentially be optimized and unnecessary treatment related morbidities from unsuccessful larynx treatments could be avoided. However, there are still no clinical or molecular biomarkers validated in standard practice at present.

$\gamma \mathrm{H} 2 \mathrm{AX}$ is a component of the histone octamer in nucleosomes. It is phosphorylated (pH2AX) by kinases such as ataxia telangiectasia mutated (ATM) and ATMRad3-related (ATR) upon DNA damage. PH2AX is involved in recruiting DNA repair proteins in response to the presence of DNA double-strand breaks (DSB) and therefore it has been studied as a biomarker of DNA damage for new drug development. As such, the presence and magnitude of $\mathrm{pH} 2 \mathrm{AX}$ is an indication of persistent, unrepaired DNA damage [28]. pH2AX induction appears within minutes in cells after DNA damage and reaches maximum levels after 30 minutes. The repair process includes the phosphorylation of hundreds to thousands $\gamma \mathrm{H} 2 \mathrm{AX}$ surrounding the DSB site in order to form a focus that open the chromatin structure and serve as a platform for the accumulation of factors involved in the DNA damage response [29]. $\gamma \mathrm{H} 2 \mathrm{AX}$ phosphorylation has been studied as prognostic biomarker in early operable non-small cell lung cancer (NSCLC) and endometrial carcinomas. In the NSCLC study, low levels of phosphorylated $\gamma \mathrm{H} 2 \mathrm{AX}$ correlated with better survival outcomes. The combination of wild type p53 and low-phosphorylated $\gamma \mathrm{H} 2 \mathrm{AX}$ phenotype showed also better survival. In the endometrial trial, $\mathrm{p}-\gamma \mathrm{H} 2 \mathrm{AX}$ positively correlated with $\mathrm{p} 53$ levels although the relation with survival could not be proved. However, in both studies patients were treated with surgery and not with radiotherapy $[30,31]$.

Our goal was to determine whether $\mathrm{pH} 2 \mathrm{AX}$ by itself or in combination with other molecular and clinical findings could be a prognosis biomarker for laryngeal carcinomas treated with RT alone or CTRT. 


\section{RESULTS}

\section{Clinical cohort description}

Patients were mainly male (93.7\%) with squamous carcinoma histopathology (100\%) and good general condition (PS 0-1 $=96.8 \%$ ). Tumors were more frequently localized in the supraglottic (58.7\%) and $74.6 \%$ were stage III. Nodal involvement was observed in $25.4 \%$ of the patients and $6.3 \%$ had primary T4 extension. Pretreatment tracheotomy was required for $31.7 \%$ patients. Organ preservation approaches include B or CTRT $(74.6 \%)$, RT $(14.3 \%)$, or ICT-B/CTRT $(9.5 \%)$ (Table 1). Most of the patients received concurrent CT or B during RT $(82.5 \%)$. The preferred treatment was cisplatin $100 \mathrm{mg} / \mathrm{m} 2$ on days 1,22 , and 43 of radiotherapy (73\%) followed by weekly cisplatin $40 \mathrm{mg} / \mathrm{m} 2(11.5 \%)$ and cetuximab (11.5\%). Carboplatin was selected for only $4 \%$ of patients.

At the time of the analysis, 20 (32\%) deaths and 29 (46\%) recurrences had occurred with a median followup of 29 months (m). Locoregional relapse occurred in $19(30 \%)$ patients, $7(11 \%)$ presented locoregional plus distant metastases, and $3(4.8 \%)$ only distant metastases; of them, $14(48.3 \%)$ were candidates for salvage surgery. Laryngoesophageal dysfunction (LD) occurred in 51\% of the total; main reasons for LD were tumoral local recurrence $(75 \%)$ followed by the need of a tracheostomy of feeding tube (15.6\%). Mean OS was $58 \mathrm{~m}(47.7-68 \mathrm{~m}$, CI 95\%), LDS $46 \mathrm{~m}$ (36-55.5m, CI 95\%), and LRC $54.6 \mathrm{~m}$ (44-65 m, CI 95\%). Moreover, 2-year LRC rate was 63\%. The 2-year cumulative proportion of patients with larynx preservation and OS were $57 \%$ and $80 \%$ respectively. Lymph node involvement was associated with worse OS (N0: $64.2 \mathrm{~m}$ vs N1/2: $26.8 \mathrm{~m}, p<0.01$ ) but not with LDS (46.8 vs 24.6, $p=0.6$ ) (Figure 1B and 1A). Tumor local extension impacted negatively on both OS and LDS (OS non-T4 $60.7 \mathrm{~m} v s$ T4 $22.5 \mathrm{~m}$; LDS non-T4 $48.5 \mathrm{~m} v s$ T4 $7.3 \mathrm{~m}$, both $p=.001$ ) (Figure 1D and 1C). Furthermore, patients who required pretreatment tracheotomy (PT) had worse OS (37.2 $\mathrm{m} v s 61.8 \mathrm{~m}, p=0.051)$ and LDS (19.6 m vs $55.4 \mathrm{~m}, p=0.001$ ) (Figure 1F and 1E). Therefore, our cohort behaves similarly to others reported in the literature $[16,21]$.

\section{Cisplatin and radiotherapy as prognostic markers in larynx cancer}

As per the RTOG 0129 phase III clinical trial results, patient were classified by the dose of cisplatin received during the radiation treatment. In total, 52.4\% reached the optimal dose of cisplatin during radiotherapy whereas $17.5 \%$ could not reach the cisplatin optimal dose, $12.7 \%$ did not receive any radiosensitizer, and $14.3 \%$ were treated with other radiosensitizers. 3.1\% were unknown.
Cisplatin optimal dose $(\geq 200 \mathrm{mg} / \mathrm{m} 2)$ was associated with better outcomes for survival although this was statistically significant for LDS (OS: $67 \mathrm{~m}$ vs 39 $\mathrm{m}, p=0.073$; LDS: $56 \mathrm{~m}$ vs $24 \mathrm{~m}, p=0.017$; LRC: 60.4 $\mathrm{m} v s 29 \mathrm{~m}, p=0.12$ ) (Figure 2B and 2A). Receiving an optimal dose of cisplatin showed better LDS $(p=0.023)$ than lesser doses $(\mathrm{HR}=0.24)$, other radiosensitizers (HR $=0.32)$, and no concurrent radiosensitizers $(\mathrm{HR}=0.65)$. However, this benefit was not observed for OS probably because the analysis did not take into account patients that needed salvage laryngectomy and did not preserve the organ.

On the other hand, total dose of radiation delivered was $70 \mathrm{~Gy}$ as per standard local guidelines. Patients that completed radiotherapy within 8 or 9 weeks were compared to those that suffered interruptions or delays but no differences were found in terms of OS or LDS between groups (Figure 3).

\section{pH2AX in larynx tumor samples}

Out of 63 samples only 53 were analyzed for pH2AX expression either due to technical problems or because they did not contain any tumor cellularity. Positive pH2AX expression, considered as any percentage of tumoral nuclei with positive staining, was shown in $46(86.8 \%)$ samples with a range of 1 to 70 and median expression of 10 (Figure 4A). In order to distinguish a cutoff point for $\mathrm{pH} 2 \mathrm{AX}$ levels a ROC curve was performed and punctuation of 5.25 score chosen (supplementary Figure 1). Levels of $\mathrm{pH} 2 \mathrm{AX}$ were equally distributed among tumor grades (Figure 4B) suggesting independence from this clinical feature, as the Chi-square test showed no differences between groups $(p=0.8)$.

When measured as a continuous variable, $\mathrm{pH} 2 \mathrm{AX}$ had a significant positive influence with better LDS outcomes (HR 0.95, $p=0.02$ ), although this was not significant for OS. As a dichotomous variable, a trend towards better OS, LDS and LRC was observed but just LDS was statistically significant in the multivariate analysis (HR 0.26, $p=0.02$ ) (Table 2) (Figure 3C, 3D and 3E).

\section{pH2AX and clinical findings}

We also studied the potential correlation between $\mathrm{pH} 2 \mathrm{AX}$ and clinical findings such as tumor localization, tumoral stage, smoking habit, alcohol consumption and acute toxicity development with no statistically significant association. These results suggest $\mathrm{pH} 2 \mathrm{AX}$ to be an independent prognostic factor, as it remains significant after controlling for these variables. 
Table 1: Population characteristics and treatment

\begin{tabular}{|c|c|c|}
\hline Population characteristics & No. & $\%$ \\
\hline Mean age & \multicolumn{2}{|c|}{63.7 years } \\
\hline Male & 59 & 93.7 \\
\hline Squamous cell carcinoma & 63 & 100.0 \\
\hline Smokers of $\geq 10$ pack-years & 59 & 93.7 \\
\hline Regular alcohol intake & 45 & 71.4 \\
\hline PS 0-1 & 61 & 96.8 \\
\hline Pretreatment tracheotomy & 20 & 31.7 \\
\hline \multicolumn{3}{|l|}{ Cigarette smoking } \\
\hline Current smokers & \multirow{3}{*}{$\begin{array}{l}43 \\
18 \\
2\end{array}$} & \multirow{3}{*}{$\begin{array}{l}68.3 \\
28.6 \\
3.2\end{array}$} \\
\hline Former smokers & & \\
\hline Never smokers & & \\
\hline \multicolumn{3}{|l|}{ Localization } \\
\hline Supraglottic & \multirow{3}{*}{$\begin{array}{l}37 \\
24 \\
2\end{array}$} & \multirow{3}{*}{$\begin{array}{l}58.7 \\
38.1 \\
3.2\end{array}$} \\
\hline Glottic & & \\
\hline Subglottic & & \\
\hline \multicolumn{3}{|l|}{ TNM Staging } \\
\hline II & \multirow{3}{*}{$\begin{array}{l}6 \\
47 \\
10\end{array}$} & \multirow{3}{*}{\begin{tabular}{|l}
9.5 \\
74.6 \\
15.9
\end{tabular}} \\
\hline III & & \\
\hline IV & & \\
\hline Treatment approach & \multirow{5}{*}{$\begin{array}{l}1 \\
9 \\
47 \\
6\end{array}$} & \multirow{5}{*}{$\begin{array}{l}1.6 \\
14.3 \\
74.6 \\
9.5\end{array}$} \\
\hline Surgery & & \\
\hline Radiotherapy & & \\
\hline $\mathrm{B} / \mathrm{CTRT}$ & & \\
\hline ICT-B/CTRT & & \\
\hline
\end{tabular}

PS: Performance status-ECOG; B/CTRT: bio/chemoradiotherapy; ICT-B/ CTRT: induction chemotherapy followed by bio/chemoradiotherapy.

\section{pH2AX relationship with cisplatin and radiotherapy}

The total dose of cisplatin was not associated with $\mathrm{pH} 2 \mathrm{AX}$ levels $(p=0.4)$. We created a variable with two categories from $\mathrm{pH} 2 \mathrm{AX}$ and cisplatin, in which one had a potential favorable prognosis (high-pH2AX levels, and optimal dose of cisplatin, $\geq 200 \mathrm{mg} / \mathrm{m} 2$ ), and the other unfavorable prognosis (low-pH2AX levels, and/ or suboptimal dose of cisplatin $<200 \mathrm{mg} / \mathrm{m} 2$ or other radiosensitizers due to the low number of patients). The favorable prognosis group correlated with increased OS, LDS (OS: $72 \mathrm{~m} v s 38.6 \mathrm{~m}, p=0.03$; LDS $66.9 \mathrm{~m} v s 27 \mathrm{~m}$, $p=0.019)$. LRC was not statistically significant $(p=0.17)$ although there was a trend towards better outcomes in the good prognostic subgroup (69.9 $\mathrm{m}$ vs $35.1 \mathrm{~m}$ ) (Figure 5A, $5 \mathrm{~B}$ and $5 \mathrm{C}$ ). Moreover, the unfavorable prognosis group correlated with worse OS (HR $=3.66, p=0.044)$, and LDS $(\mathrm{HR}=3.38, p=0.028)$. LRC has a not statistically significant $\mathrm{HR}(\mathrm{HR}=2.4, p=0.188)$.

We also tried to stablish whether high-pH2AX and no radiotherapy delays could impact on survival but no differences were found for both OS and LDS.

\section{Correlation of pH2AX with p53 and KI67}

We also analyzed other markers for proliferation such as KI67 or the activated form of ERK (phosphorylated ERK, ERK-p), and apoptosis such as mutant (m) p53 or activated AKT (phosphorylated AKT, AKT-p). Our cohort showed a percentage of positive samples for ERK-p or AKT-p, but these groups did not show correlation with pH2AX expression (data not shown). KI67 in combination with $\mathrm{pH} 2 \mathrm{AX}$ was not significant in any combination (data not shown), being $\mathrm{pH} 2 \mathrm{AX}$ also independent of the proliferative capability of the tumor. Our results showed no correlation between $\mathrm{p} 53$ and $\mathrm{pH} 2 \mathrm{AX}$ although there was a relation towards increased $\mathrm{pH} 2 \mathrm{AX}$ with negative P53 ( $<5 \%$ positive nuclei) that was not statistically significant $(p=0.33)$.

However, in our cohort p53 samples positive (measured as $>5 \%$ positive nuclei) (Figure 6A, + p53) correlated with worse OS $(-\mathrm{p} 53=50 v s+\mathrm{p} 53=35.6 \mathrm{~m}$, $p=0.047$ ) (Figure 6B) consistent with previous literature [34].

P53 and pH2AX were combined into a new variable with the following categories: potential good 


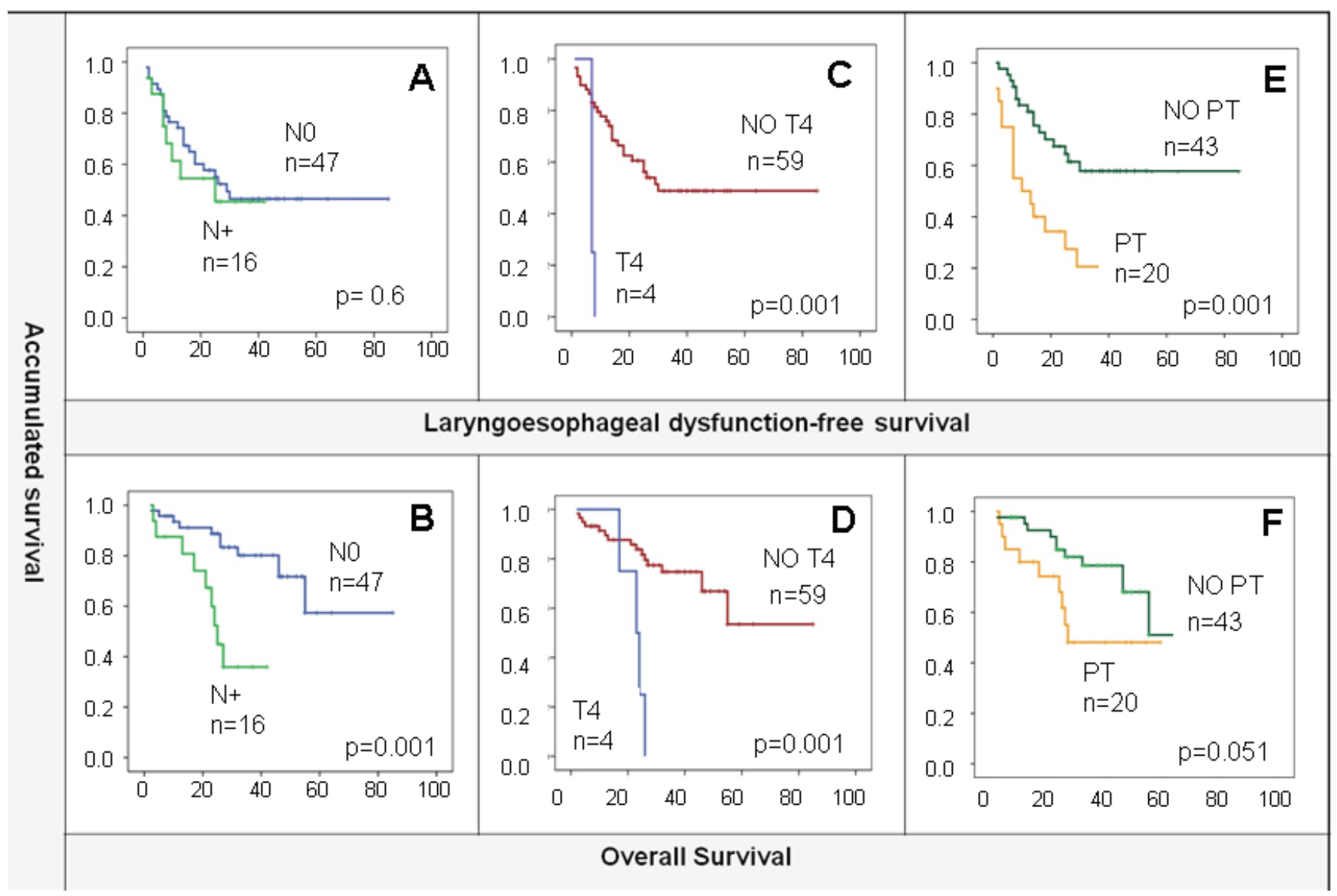

Figure 1: A. and B. N0 compared with N positive LDS/OS. OS was better in the patients who had no lymph node involvement. C. and D. T4 local tumor extension shows worse OS and LDS than the rest of patients. E. and F. worse LDS and OS is observed in patients who required pretreatment tracheotomy $(\mathrm{PT})$.

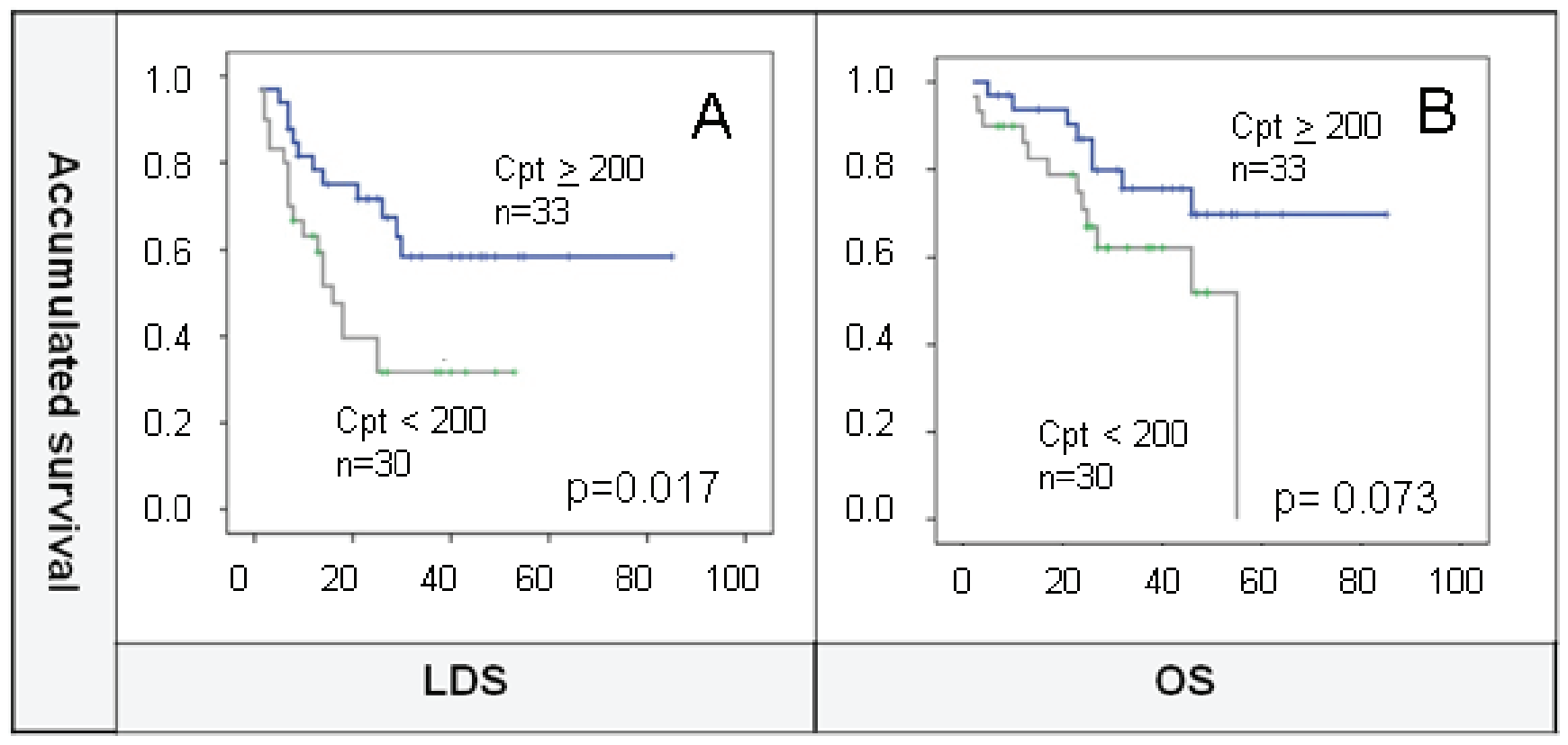

Figure 2: A. and B. Cisplatin (Cpt) optimal dose ( $\geq 200 \mathrm{mg} / \mathrm{m} 2)$ showed significant LDS benefit that was not maintained for OS. 
Table 2: LDS and OS multivariate analysis

\begin{tabular}{|l|l|l|l|l|l|l|l|}
\hline LDS & HR & $\boldsymbol{p}$-value & CI & & OR & $\boldsymbol{p}$-value & CI \\
\hline PT & 1.41 & 0.59 & $0.39-5.08$ & PT & 0.96 & 0.98 & $\begin{array}{l}0.17- \\
5.58\end{array}$ \\
\hline $\begin{array}{l}\text { Non-primary T4 } \\
\text { extension }\end{array}$ & 0.09 & 0.00 & $0.02-0.49$ & N negative & 0.65 & 0.03 & $\begin{array}{l}0.01-0- \\
74\end{array}$ \\
\hline $\begin{array}{l}\text { Cisplatin } \\
\text { 200mg/m }\end{array}$ & 0.09 & 0.00 & $0.02-0.43$ & $\begin{array}{l}\text { Cisplatin } \\
\text { >200mg/m }\end{array}$ & 0.33 & 0.29 & $\begin{array}{l}0.04- \\
2.56\end{array}$ \\
\hline High-pH2AX & 0.26 & 0.02 & $0.09-0.78$ & High-pH2AX & 0.57 & 0.46 & $\begin{array}{l}0.13- \\
2.55\end{array}$ \\
\hline KI 67 & 1.03 & 0.15 & $0.99-1.06$ & KI 67 & 1.06 & 0.038 & $\begin{array}{l}1.00- \\
1.12\end{array}$ \\
\hline MAP17 & 1.01 & 0.63 & $0.99-1.02$ & MAP17 & 0.98 & 0.05 & $\begin{array}{l}0.95- \\
1.00\end{array}$ \\
\hline P53 & 0.99 & 0.37 & $0.56-1.02$ & P53 & 1.03 & 0.12 & $\begin{array}{l}0.99- \\
1.07\end{array}$ \\
\hline pERK & 0.99 & 0.35 & $0.97-1.01$ & pERK & 1.01 & 0.65 & $\begin{array}{l}0.98- \\
1.04\end{array}$ \\
\hline pAKTP & 0.99 & 0.41 & $0.98-1.01$ & pAKT & 0.98 & 0.16 & $\begin{array}{l}0.96- \\
1.01\end{array}$ \\
\hline
\end{tabular}

LDS: laryngoesophageal dysfunction-free survival. OS: overall survival. HR: hazard ratio. CI: confidence interval. PT: pretreatment tracheotomy. N: pathological lymph nodes.

prognosis phenotype (negative $\mathrm{p} 53$ and high-pH2AX) and unfavorable prognosis phenotype (positive p53 and low$\mathrm{pH} 2 \mathrm{AX})$. Although there was an apparent relation towards better outcomes in the good prognosis phenotype, this was not significant for both OS and LDS (OS: $48.6 \mathrm{~m} v s 39 \mathrm{~m}$, $p=0.39$; LDS: $38.8 \mathrm{~m}$ vs $24.4 \mathrm{~m}, p=0.068$ ) (Figure 6C and $6 \mathrm{D})$.

\section{Correlation of pH2AX and MAP17}

We have recently shown that MAP17, a small non-glycosylated membrane protein overexpressed in carcinomas, expression analyzed by immunohistochemistry is associated with OS $(p<$ $0.001)$ and LDS $(p=0.002)$ [32]. MAP17 increases endogenous ROS $[35,36]$. Since ROS is a well-known mediator of DNA damage [37], we measured whether $\mathrm{pH} 2 \mathrm{AX}$ correlated with MAP17 expression and whether the combination of both markers could strength the predictability of responses.

We found that patients with high levels of MAP17 and subject to optimal doses of cisplatin had better LDS (58.6 $\mathrm{m}$ vs $32.6 \mathrm{~m}, p=0.053)$ and OS (76.2 m vs 40.9 $\mathrm{m}, p=0.005)$ than patients with low MAP17 or not subject to optimal doses of cisplatin (Figure 7A and 7B). Furthermore, patients with high levels of MAP17 and high-pH2AX, denoting higher structural DNA-damage, conform the group of better prognosis after therapy (Figure 7C and 7D).

Moreover, patients with high-MAP17, high-pH2AX and optimal dose of cisplatin had better OS and LDS than the rest of the population (Figure 7E and 7F), and when compared with poor prognosis phenotype (low-MAP17, low-pH2AX and suboptimal cisplatin dose) (Figure 7G and $7 \mathrm{H})$.

\section{DISCUSSION}

In this manuscript, we have shown that $\mathrm{pH} 2 \mathrm{AX}$ has a prognostic role in patients with laryngeal cancer. We hypothesize, taking into account the combined analysis with p53 and MAP17, that the DDR pathway could have an essential role in laryngeal cancer. Although further research is needed, we think that our results are opening a new window to identify biomarkers that in the future may allow changes in clinical practice, as to date there are no biomarkers that could identify those patients that will benefit from radiotherapy-based treatments instead of surgery.

We found that $\mathrm{pH} 2 \mathrm{AX}$ was related to LDS (High$\mathrm{pH} 2 \mathrm{AX}$ HR $0.26, p=0.02$ ) in a cohort of 53 patients with larynx cancer. When analyzed together $\mathrm{pH} 2 \mathrm{AX}$ expression and dose of cisplatin received during radical treatment, there is a significant correlation with survival (high$\mathrm{pH} 2 \mathrm{AX}$ and optimal dose of cisplatin 72 months vs 38.6 months, $p=0.03$ ) and LDS (high-pH2AX and optimal dose of cisplatin 66.9 months vs 27 months, $p=0.019$ ). Our data suggest that inherent DDR pathway activation (measured by the end-point of phosphorylation of H2AX) is a valuable prognostic marker in patients with laryngeal carcinoma who received preservation approaches. Our data also show the importance of performing optimal 
cisplatin treatment for tumor response. However, the fact that unexpected radiotherapy delays and interruptions did not affect survival in our cohort could be explained to dose compensations. Radiobiological-based calculations were performed in those patients in order to achieve an equivalent biological effectiveness by adding some more fractions to the overall treatment.

Tumor cells from clinical specimens show constitutive activation of DNA damage signalling as demonstrated by the presence of $\mathrm{gH} 2 \mathrm{AX}$ phosphorylation and other DDR signalling proteins [38-40]. This DDR activation was found to peak at early stage tumors, persisting further among malignant tumors mostly by inactivating p53 gatekeeper [40]. It has been proposed that the DDR-network may serve as an inducible barrier to control the initial steps of tumor development by inducing p53-dependent senescence or apoptosis [38-40]. Further ongoing chronic DDR activation favours the outgrowth of malignant clones with genetic or epigenetic defects in DNA-repair mechanism such as those involved in the DDR pathway [40]. Our samples, from already malignant tumors (stages II-IV), in which only a subset of them

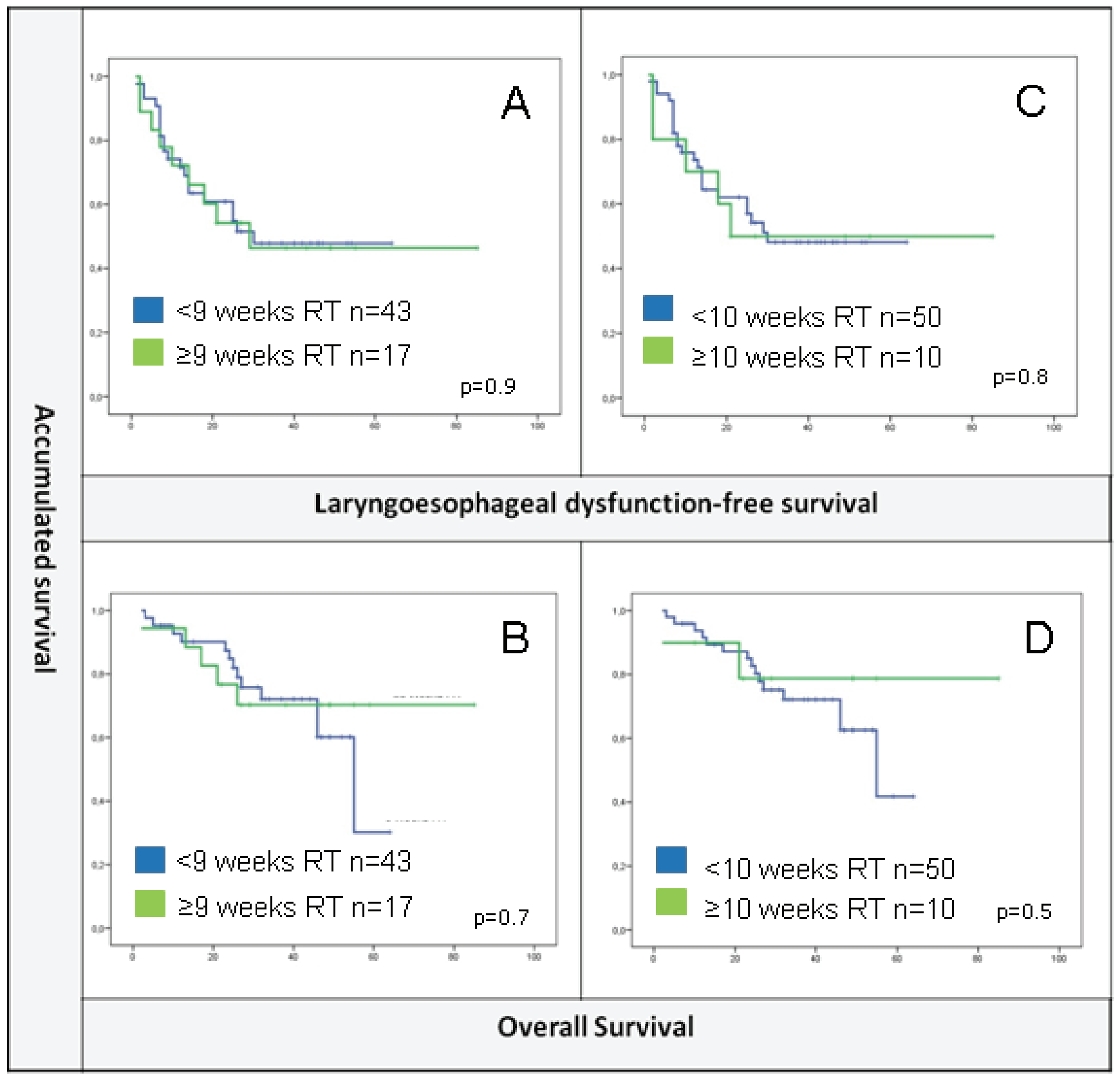

Figure 3: A. and B. No differences were found for radiotherapy delivered within less than 9 weeks or $\geq 9$ weeks in terms of LDS or OS. $\mathrm{C}$ and D. Same results for a cut-off of 10 weeks. 
showed mutant p53, correlated with worse onset of the disease. It is likely DNA-damage defects inducing DDR activation have been carried through the malignant process and it is possible that other proteins are mutated in the process avoiding the requirement for $\mathrm{p} 53$ inactivation.

$\mathrm{pH} 2 \mathrm{AH}$ is a broad DNA damage marker that appears under different physiological conditions. Senescent cells display molecular characteristics of DNA damage [4143]. These markers include nuclear foci of phosphorylated histone $\mathrm{H} 2 \mathrm{AX}$, the localization at double-strand break sites of DNA-repair and DNA-damage checkpoint factors, such as 53BP1, MDC1 and NBS1 [44-46]. Senescent cells also contain activated forms of the DNA-damage checkpoint kinases Chk1 and Chk2. During replicative senescence, markers of a DNA damage response localize at telomeres $[45,47]$, indicating that the DNA damage response is triggered by telomere shortening [48]. Similarly, the redox potential also results in DNA damage and senescence [49]. Very interestingly, oncogene-induced senescence has been found to induce DNA-damage due to an excess of replication forks. This oncogenic-induced hyper-replication signal, or replication stress, is associated with persistent DNA-damage $[50,51]$ inducing senescence [52]. Therefore, not only senescence is viewed as a response to DNA-damage, but DNA-damage as a marker of senescence. In that sense, high $\mathrm{pH} 2 \mathrm{AX}$ appeared in early stage tumors and is a marker of good prognosis $[38,53,54]$. However, in our cohort, $\mathrm{pH} 2 \mathrm{AX}$ levels are increased in advanced stages of tumors, and contrarily to this hypothesis, are a marker of bad prognosis, indicating that our $\mathrm{pH} 2 \mathrm{AX}$ observations are not due to cellular senescence, neither by continuous proliferation nor by replication stress.

In that line, phosphorylation of $\mathrm{H} 2 \mathrm{AX}$ is not always a marker of DNA damage. It also can be a marker of activated mTOR, eliciting replicative stress and a
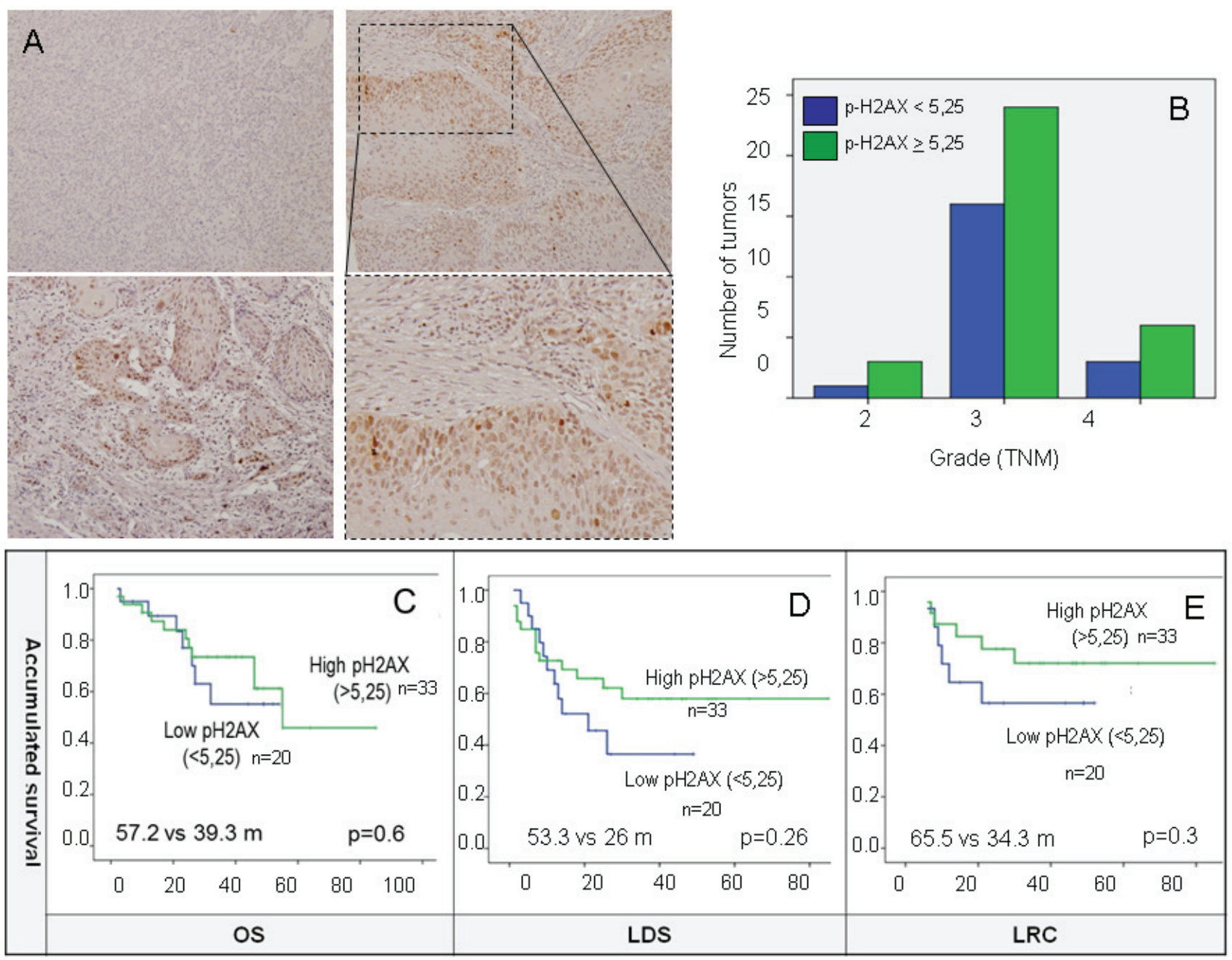

Figure 4: A. Positive pH2AX expression, considered as nuclei staining was shown in $46(86.8 \%)$ samples. B. Levels of pH2AX are equally distributed among tumor stages. C., D. and E. high-pH2AX show a trend towards better OS, LDS and LRC not statistically significant in the Kaplan-Meier analysis. 5.25 as indicated by the ROC curve were used as cut-off for defining high and low expression of $\mathrm{pH} 2 \mathrm{AX}$ for survival analysis. 


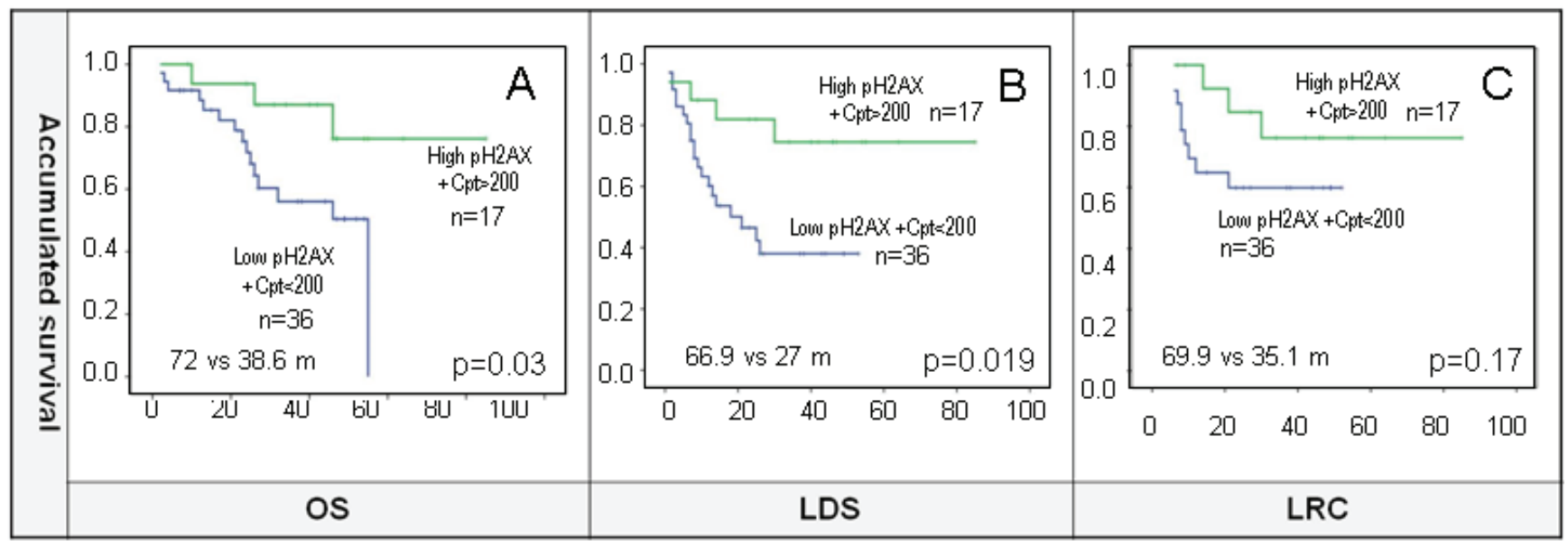

Figure 5: A., B. and C. $\mathrm{pH} 2 \mathrm{AX}$ and dose of concomitant cisplatin were combined in a new variable where high-pH2AX and cisplatin $(\mathrm{Cpt}) \geq 200 \mathrm{mg} / \mathrm{m} 2$ was considered as good prognosis phenotype category. The results show improved OS and LDS in this subgroup, and a trend towards better LRC. 5.25 as indicated by the ROC curve were used as cut-off for defining high and low expression of pH2AX for survival analysis.
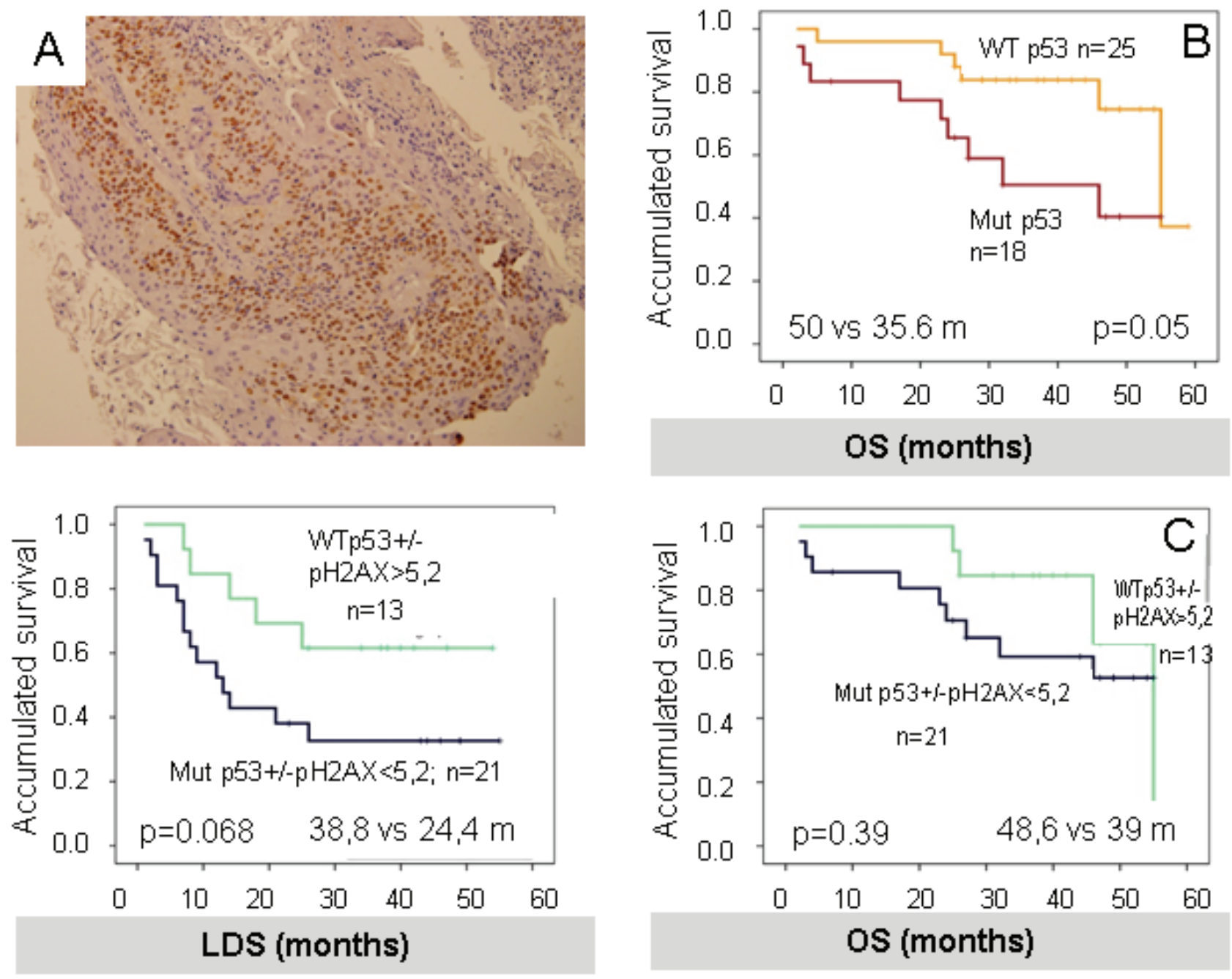

Figure 6: A. P53 was measured as $>5 \%$ positive nuclei, as shown in the picture. B. positive P53 (+ P53) correlates with worse OS in our cohort. C. and D. results of the combination of P53 and pH2AX in a new variable. Although there was a trend towards better outcomes in the good prognosis phenotype which included negative P53 (-P53) and high-pH2AX, this was not statistically significant for OS and LDS. 
pseudo DNA-damage in senescent cells [46, 51, 55-58]. The dynamics of senescence exhibit 2 different steps: cell cycle arrest and further acquisition of senescence features, which includes permanent arrest, termed geroconversion [51, 58-60]. If geroconversion is not activated, cells are only transiently arrested with the possibility of resuming growth once the proliferation constraints have been eliminated [44, 61]. It has also been shown that if mTOR is activated under conditions of proliferative arrest, then arrest becomes permanent and the cell undergoes senescence [59, 60, 62]. Under these conditions of cell cycle arrest and mTOR activation, the phosphorylation of $\mathrm{H} 2 \mathrm{AX}$ is launched, becoming a marker of cellular senescence [46, 52, 55, 62]. In fact, rapamycin treatment, which inhibits $\mathrm{mTOR}$, can divert senescence into quiescence, allowing the cell to resume growth once conditions are more favorable [63-66]. Since $\mathrm{mTOR}$ is the master regulator of protein synthesis [67], it has been proposed that this contribution is due to the function of mTOR as a sensor of cellular nutrients and energy status as well as growth factor signals [68, 69]. However, it has also been reported that mTOR activation in the context of growth arrest is perceived by the cells as and unwanted oncogenic signal, activating the replicative stress and pseudo DNA-damage signaling [46, 52, 55, 62]. In any case, high levels of $\mathrm{pH} 2 \mathrm{AX}$ as marker of cellular senescence should be associated to better prognosis, and to some extent to early stage tumors. However, it will be of interest to correlate the levels of $\mathrm{pH} 2 \mathrm{AH}$ with those of mTOR activation in laryngeal tumors to provide a more accurate hypothesis of the $\mathrm{pH} 2 \mathrm{AH}$ inducers.

Our data show that high levels of $\mathrm{pH} 2 \mathrm{AX}$ correlate with better prognosis after treatment with DNA-damage agents such as cisplatin and radiotherapy, especially if cisplatin is given at optimal doses. These data are suggestive of a collaboration of DDR pathway activation, perhaps as an indicator of low DNA-repair ability and DNA-damaging agents in tumor therapy. The fact that doses of cisplatin are important for survival (Figure 2) seems to confirm this hypothesis. In line with this, wtP53 with high levels of $\mathrm{pH} 2 \mathrm{AX}$ conforms a subgroup of good prognosis (Figure 6) suggesting that P53 activity is essential to drive physiological response to apoptosis (or senescence) of DNA-damage agents in tumors with DDR activated.

These data are opposite to the found in early operable non-small cell lung cancer (NSCLC). In this study, low levels of $\mathrm{pH} 2 \mathrm{AX}$ correlated with better survival outcomes. The combination of wild type p53 and low-phosphorylated $\gamma \mathrm{H} 2 \mathrm{AX}$ phenotype showed also better survival. However, NSCLC patients were treated with surgery and not with radiotherapy [30]. This lack of treatment with radiotherapy could be the cause of the different behavior respect the $\mathrm{pH} 2 \mathrm{AX}$. Radiotherapy increases oxidative stress and reactive oxygen species that in combination with preexisting DNA damage can increase cell damage above threshold inducing increased tumor efficacy. Our data support this hypothesis since combination with another ROS-inducing agent such as cisplatin is essential to gain better survival in these patients. Furthermore, the combination of MAP17, a known ROS-inducing oncogene $[32,35,36,70]$ also supports the essential role of radiotherapy in this response.

We have recently shown that MAP17 levels, a small non-glycosylated membrane protein overexpressed in carcinomas, are associated with overall survival $(p<$ $0.001)$ and laryngoesophageal dysfunction-free survival ( $p$ $=0.002$ ) [32]. MAP17 increases endogenous $\operatorname{ROS}[35,36$, 70]. ROS are well known mediators of DNA damage [37]. Our data suggest that high levels of MAP17 induced ROS that in turn increases DNA-damage and DDR signaling. Upon further DNA-damage and further increase in ROS molecules induced by cisplatin and RT treatment, tumors with higher oxidative stress (higher MAP17, higher ROS denoted by higher $\mathrm{pH} 2 \mathrm{AX}$ ), are more suitable to undergo apoptosis in the presence of P53 activity. Therefore, our data seems to confirm that $\mathrm{pH} 2 \mathrm{AX}$ is a marker of structural DNA-damage in the laryngeal tumors that may become a novel and valuable prognostic biomarker for laryngeal carcinoma.

\section{MATERIALS AND METHODS}

\section{Patient's characteristics and treatment}

We evaluated 63 patients with larynx cancer from August 2005 to February 2014. However, out of the 63 tumoral samples, only 53 of them could be studied. All samples were obtained from diagnostic biopsies before any treatment. All patients completed the informed consent form and the project was approved by the local ethical committee at the HUVR (PI13/059). Patients received treatment in our institution but tumor samples were obtained from four different national hospitals where the diagnosis was made. Eligibility criteria for preservation include patients with stage II-IV laryngeal tumors that had no contraindication for chemotherapy and/or radiotherapy, significant cartilage destruction, or more than $2 \mathrm{~cm}$ tumoral invasion of the base of the tongue. TNM Staging System for the Larynx (7th ed., 2010) was used for tumor classification. This cohort has been previously reported in [32].

\section{Tissue acquirement and preparation}

Formalin-fixed, paraffin-embedded tissue sections from 63 laryngeal carcinomas were selected with the collaboration of the Andalusian Health Care Biological Resource Centre. Histological characterization of all samples was done by Hematoxylin and Eosin staining, 


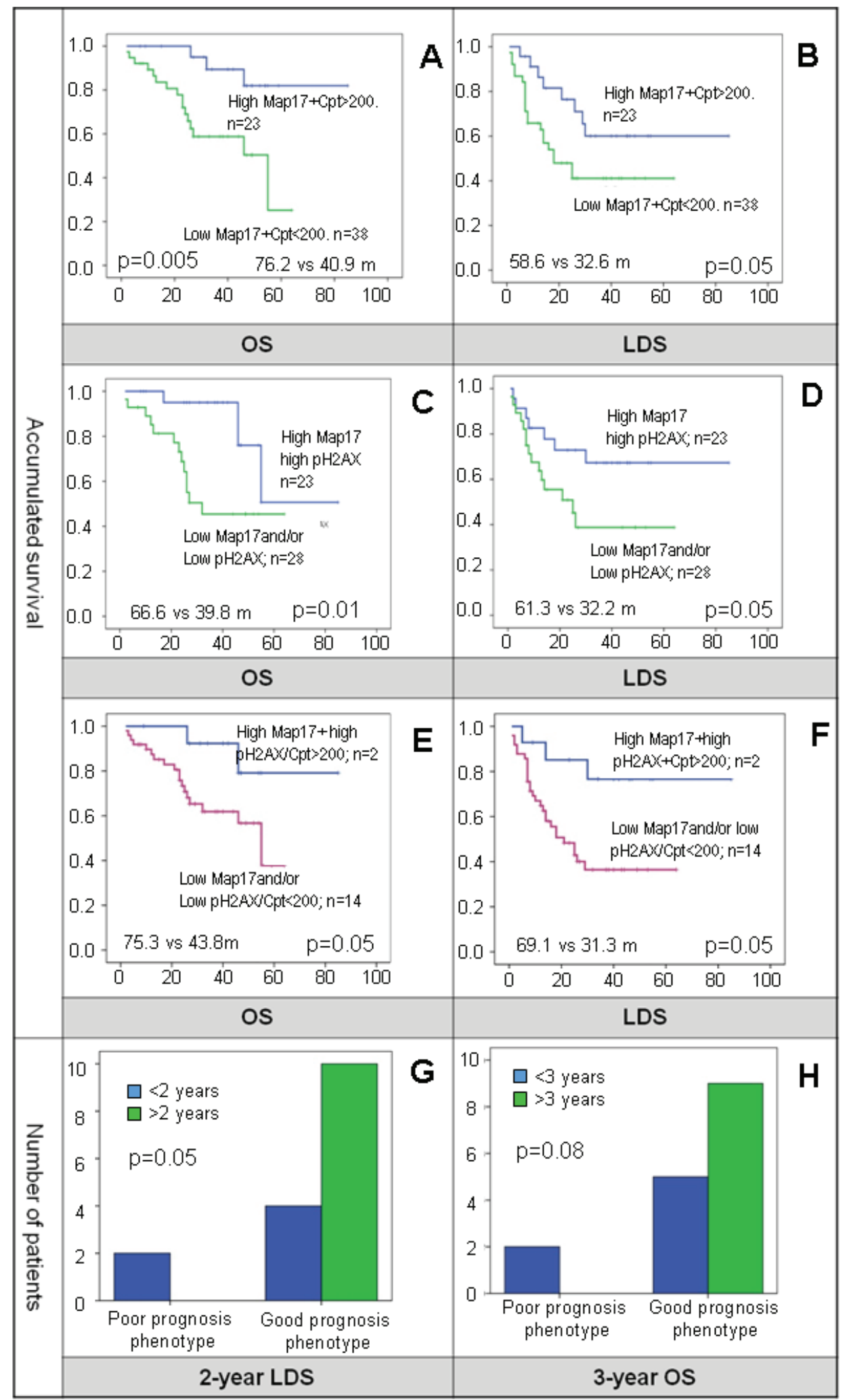

Figure 7: A. and B. the combination of high-MAP17 and optimal doses of cisplatin (Cpt) showed better OS and LDS. C. and D. patients with high-MAP17 and high-pH2AX with higher structural DNA-damage showed to have better OS and LDS. E. and F. survival for patients with high-pH2AX, high-MAP17 and optimal dose of cisplatin was statistically better. G. and H. the subgroup of patients with high-pH2AX, high-MAP17 and cisplatin optimal dose patients was compared to the patients that had low-pH2AX, low-MAP17 and did not complete cisplatin. Although limited in numbers, none of the patients with poor prognosis phenotype reached more than 2-years LDS or more than 3-years OS. 
followed by immunohistochemistry (IHQ) analysis of tissue microarrays (TMA).

\section{Immunohistochemistry}

Three-micrometer slices were sectioned from the TMA block and applied to coated, immunochemistry slides (DAKO, Glostrup, Denmark). The slides were baked overnight in a $56^{\circ} \mathrm{C}$ oven, deparaffinized in xylene for $20 \mathrm{~min}$, rehydrated through a graded ethanol series and washed with PBS. A heat-induced epitope retrieval step was performed by heating a slide in a solution of sodium citrate buffer $\mathrm{pH} 6.5$ for $2 \mathrm{~min}$ in a conventional pressure cooker. After heating, the slides were incubated with proteinase $\mathrm{K}$ for $10 \mathrm{~min}$ and rinsed in cool running water for $5 \mathrm{~min}$. Endogenous peroxide activity was quenched with $1.5 \%$ hydrogen peroxide (DAKO) in methanol for 10 minutes, and incubation with the primary antibodies anti-gamma H2A.X (phospho S139) antibody (ab11174 from Abcam) and anti-p53: p53 FL 393 (sc-6243 from Santa Cruz); was performed for $40 \mathrm{~min}$. After incubation, immunodetection was performed with the EnVision (DAKO, Glostrup, Denmark) visualization system using diaminobenzidinechromogen as the substrate, according to the manufacturer's instructions. Immunostaining was performed in a TechMate 500 automatic immunostaining device (DAKO) and measured through a doubleblind visual assessment using microscopic observation according to the anatomopathological experience of pathologists. Sample scoring was performed by microscopic analysis, considering the percentage of nuclei stained cells.

\section{Statistical analysis and definitions}

Kaplan-Meier method was used for survival analysis, using Cox Proportional Hazards model to adjust for the explanatory variables, obtain the p-values and estimate the hazard ratios (HR). Multivariate logistic regression was used to obtain odds ratio (OR) and confidence intervals (CI 95\%). Pearson's correlation measured dependence between quantitative variables. A receiver operating characteristic (ROC) curve was performed to assess $\mathrm{pH} 2 \mathrm{AX}$ cutoff point (two-year OS), which we checked using the optimal Youden index-based point. In addition, a log-rank test compared the survival distributions between high and low PH2AX both as a single variable and in combination with cisplatin optimal dose, MAP17 and p53. Categorical data were studied with contingency tables that included Chi-square statistics. Calculations were performed using SPSS 15.0 software.

OS has been defined as the length of time from diagnosis until the last medical record. LCR was measured as length of time from diagnosis until the relapse or last medical record, in those patients who did not develop distant metastases or died due to different causes than the tumor. For laryngoesophageal dysfunction-free survival (LDS) we adopted Lefebvre Larynx Preservation Consensus Panel that included as endpoint events: death, local relapse, total or partial laryngectomy, tracheotomy at two or more years, or the presence of a feeding tube at two or more years [33].

\section{ACKNOWLEDGMENTS}

The authors thank the donors and the Andalusian Public Health System Biobank (ISCIII-Red de Biobancos RD12/0036/0017) for the human specimens used in this study. This work was supported by grants to from the Spanish Ministry of Economy and Competitivity, Plan Nacional de I+D+I 2008-2011, Plan Estatal de I+D+I 2013-2016, ISCIII (Fis: PI12/00137, PI15/00045, RTICC: RD12/0036/0028) co-funded by FEDER from Regional Development European Funds (European Union), Consejeria de Ciencia e Innovacion (CTS-6844 and CTS1848) and Consejeria de Salud of the Junta de Andalucia (PI-0135-2010 and PI-0306-2012). This work has been also possible thanks to the Plan Estatal de I+D+i 20132016, Grant PIE13/0004 co-funded by the ISCIII and FEDER funds.

\section{CONFLICTS OF INTEREST}

The authors report no conflicts of interest.

\section{REFERENCES}

1. Ferlay J, Shin HR, Bray F, Forman D, Mathers C, Parkin DM. Estimates of worldwide burden of cancer in 2008: GLOBOCAN 2008. Int J Cancer. 2010; 127: 2893-2917.

2. de Miguel-Luken MJ, Chaves-Conde M, Carnero A. A Genetic view of Laryngeal Cancer heterogeneity. Cell Cycle. 2016; 15:1202-12.

3. Talamini R, Bosetti C, La Vecchia C, Dal Maso L, Levi F, Bidoli E, Negri E, Pasche C, Vaccarella S, Barzan L, Franceschi S. Combined effect of tobacco and alcohol on laryngeal cancer risk: a case-control study. Cancer causes \& control. 2002; 13: 957-964.

4. Shangina O, Brennan P, Szeszenia-Dabrowska N, Mates D, Fabianova E, Fletcher T, t'Mannetje A, Boffetta P, Zaridze D. Occupational exposure and laryngeal and hypopharyngeal cancer risk in central and eastern Europe. Am J Epidemiol. 2006; 164: 367-375.

5. Negri E, Boffetta P, Berthiller J, Castellsague X, Curado MP, Dal Maso L, Daudt AW, Fabianova E, Fernandez L, Wunsch-Filho V, Franceschi S, Hayes RB, Herrero R, Koifman S, Lazarus P, Lence JJ et al. Family history of cancer: pooled analysis in the International Head and Neck Cancer Epidemiology Consortium. Int J Cancer. 2009; 124: 394-401. 
6. Torrente MC, Rodrigo JP, Haigentz M, Jr., Dikkers FG, Rinaldo A, Takes RP, Olofsson J, Ferlito A. Human papillomavirus infections in laryngeal cancer. Head Neck. 2011; 33: 581-586.

7. Gao X, Fisher SG, Mohideen N, Emami B. Second primary cancers in patients with laryngeal cancer: a populationbased study. Int J Radiat Oncol Biol Phys. 2003; 56: 427 435.

8. Sessions DG. Surgical pathology of cancer of the larynx and hypopharynx. Laryngoscope. 1976; 86: 814-839.

9. Singh B, Bhaya M, Stern J, Roland JT, Zimbler M, Rosenfeld RM, Har-El G, Lucente FE. Validation of the Charlson comorbidity index in patients with head and neck cancer: a multi-institutional study. Laryngoscope. 1997; 107: 1469-1475.

10. Mayne ST, Cartmel B, Kirsh V, Goodwin WJ, Jr. Alcohol and tobacco use prediagnosis and postdiagnosis, and survival in a cohort of patients with early stage cancers of the oral cavity, pharynx, and larynx. Cancer Epidemiol Biomarkers Prev. 2009; 18: 3368-3374.

11. Di Martino E, Sellhaus B, Hausmann R, Minkenberg R, Lohmann M, Esthofen MW. Survival in second primary malignancies of patients with head and neck cancer. J Laryngol Otol. 2002; 116: 831-838.

12. Raitiola H, Pukander J, Laippala P. Glottic and supraglottic laryngeal carcinoma: differences in epidemiology, clinical characteristics and prognosis. Acta Otolaryngol. 1999; 119: 847-851.

13. Zhang SY, Lu ZM, Luo XN, Chen LS, Ge PJ, Song XH, Chen SH, Wu YL. Retrospective analysis of prognostic factors in 205 patients with laryngeal squamous cell carcinoma who underwent surgical treatment. PLoS One. 2013; 8: e60157.

14. Yilmaz T, Hosal S, Ozyar E, Akyol F, Gursel B. Postoperative radiotherapy in advanced laryngeal cancer: effect on local and regional recurrence, distant metastases and second primaries. J Laryngol Otol. 2005; 119: 784-790.

15. Herchenhorn D, Dias FL, Ferreira CG, Araujo CM, Lima RA, Small IA, Kligerman J. Impact of previous tracheotomy as a prognostic factor in patients with locally advanced squamous cell carcinoma of the larynx submitted to concomitant chemotherapy and radiation. ORL; journal for oto-rhino-laryngology and its related specialties. 2008; 70: 381-388.

16. Wolf GT, Hong WK. Induction chemotherapy for organ preservation in advanced laryngeal cancer: is there a role? Head Neck. 1995; 17: 279-283.

17. Chevalier D, Laccourreye O, Brasnu D, Laccourreye H, Piquet JJ. Cricohyoidoepiglottopexy for glottic carcinoma with fixation or impaired motion of the true vocal cord: 5-year oncologic results with 112 patients. The Annals of otology, rhinology, and laryngology. 1997; 106: 364-369.

18. Silver CE, Beitler JJ, Shaha AR, Rinaldo A, Ferlito A. Current trends in initial management of laryngeal cancer: the declining use of open surgery. Eur Arch Otorhinolaryngol. 2009; 266: 1333-1352.

19. Jorgensen K, Godballe C, Hansen O, Bastholt L. Cancer of the larynx - treatment results after primary radiotherapy with salvage surgery in a series of 1005 patients. Acta Oncol. 2002; 41: 69-76.

20. American Society of Clinical O, Pfister DG, Laurie SA, Weinstein GS, Mendenhall WM, Adelstein DJ, Ang KK, Clayman GL, Fisher SG, Forastiere AA, Harrison LB, Lefebvre JL, Leupold N, List MA, O'Malley BO, Patel S et al. American Society of Clinical Oncology clinical practice guideline for the use of larynx-preservation strategies in the treatment of laryngeal cancer. J Clin Oncol. 2006; 24: 36933704.

21. Forastiere AA, Goepfert H, Maor M, Pajak TF, Weber R, Morrison W, Glisson B, Trotti A, Ridge JA, Chao C, Peters G, Lee DJ, Leaf A, Ensley J, Cooper J. Concurrent chemotherapy and radiotherapy for organ preservation in advanced laryngeal cancer. N Engl J Med. 2003; 349: 20912098.

22. Forastiere AA, Zhang Q, Weber RS, Maor MH, Goepfert H, Pajak TF, Morrison W, Glisson B, Trotti A, Ridge JA, Thorstad W, Wagner H, Ensley JF, Cooper JS. Long-term results of RTOG 91-11: a comparison of three nonsurgical treatment strategies to preserve the larynx in patients with locally advanced larynx cancer. J Clin Oncol. 2013; 31: 845-852.

23. Pignon JP, le Maitre A, Maillard E, Bourhis J, Group M-NC. Meta-analysis of chemotherapy in head and neck cancer (MACH-NC): an update on 93 randomised trials and 17,346 patients. Radiother Oncol. 2009; 92: 4-14.

24. Ang KK, Zhang Q, Rosenthal DI, Nguyen-Tan PF, Sherman EJ, Weber RS, Galvin JM, Bonner JA, Harris J, El-Naggar AK, Gillison ML, Jordan RC, Konski AA, Thorstad WL, Trotti A, Beitler JJ et al. Randomized phase III trial of concurrent accelerated radiation plus cisplatin with or without cetuximab for stage III to IV head and neck carcinoma: RTOG 0522. J Clin Oncol. 2014; 32: 29402950.

25. Ghi MG, Paccagnella A, D'Amanzo P, Mione CA, Fasan S, Paro S, Mastromauro C, Carnuccio R, Turcato G, Gatti C, Pallini A, Nascimben O, Biason R, Oniga F, Medici M, Rossi F et al. Neoadjuvant docetaxel, cisplatin, 5-fluorouracil before concurrent chemoradiotherapy in locally advanced squamous cell carcinoma of the head and neck versus concomitant chemoradiotherapy: a phase II feasibility study. Int J Radiat Oncol Biol Phys. 2004; 59: 481-487.

26. Strojan P, Vermorken JB, Beitler JJ, Saba NF, Haigentz M, Jr., Bossi P, Worden FP, Langendijk JA, Eisbruch A, Mendenhall WM, Lee AW, Harrison LB, Bradford CR, Smee R, Silver CE, Rinaldo A et al. Cumulative cisplatin dose in concurrent chemoradiotherapy for head and neck cancer: A systematic review. Head Neck. 2016; 38 Suppl 1:E2151-8. 
27. Machtay M, Moughan J, Trotti A, Garden AS, Weber RS, Cooper JS, Forastiere A, Ang KK. Factors associated with severe late toxicity after concurrent chemoradiation for locally advanced head and neck cancer: an RTOG analysis. J Clin Oncol. 2008; 26: 3582-3589.

28. Karp JE, Ricklis RM, Balakrishnan K, Briel J, Greer J, Gore SD, Smith BD, McDevitt MA, Carraway H, Levis MJ, Gandhi V. A phase 1 clinical-laboratory study of clofarabine followed by cyclophosphamide for adults with refractory acute leukemias. Blood. 2007; 110: 1762-1769.

29. Ivashkevich A, Redon CE, Nakamura AJ, Martin RF, Martin OA. Use of the gamma-H2AX assay to monitor DNA damage and repair in translational cancer research. Cancer Lett. 2012; 327: 123-133.

30. Matthaios D, Foukas PG, Kefala M, Hountis P, Trypsianis G, Panayiotides IG, Chatzaki E, Pantelidaki E, Bouros D, Karakitsos P, Kakolyris S. gamma-H2AX expression detected by immunohistochemistry correlates with prognosis in early operable non-small cell lung cancer. OncoTargets and therapy. 2012; 5: 309-314.

31. Brunner AH, Hinterholzer S, Riss P, Heinze G, Weiss K, Brustmann H. Expression of gamma-H2AX in endometrial carcinomas: an immunohistochemical study with p53. Gynecol Oncol. 2011; 121: 206-211.

32. de Miguel-Luken MJ, Chaves-Conde M, de MiguelLuken V, Munoz-Galvan S, Lopez-Guerra JL, Mateos JC, Pachon J, Chinchon D, Suarez V, Carnero A. MAP17 (PDZKIP1) as a novel prognostic biomarker for laryngeal cancer. Oncotarget. 2015; 6: 12625-12636. doi:10.18632/ oncotarget. 3470 .

33. Lefebvre JL, Ang KK, Larynx Preservation Consensus P. Larynx preservation clinical trial design: key issues and recommendations-a consensus panel summary. Int J Radiat Oncol Biol Phys. 2009; 73: 1293-1303.

34. Ashraf MJ, Maghbul M, Azarpira N, Khademi B. Expression of Ki67 and P53 in primary squamous cell carcinoma of the larynx. Indian journal of pathology \& microbiology. 2010; 53: 661-665.

35. Guijarro MV, Leal JF, Blanco-Aparicio C, Alonso S, Fominaya J, Lleonart M, Castellvi J, Ramon y Cajal S, Carnero A. MAP17 enhances the malignant behavior of tumor cells through ROS increase. Carcinogenesis. 2007; 28: 2096-2104.

36. Carnero A. MAP17 and the double-edged sword of ROS. Biochim Biophys Acta. 2012; 1826: 44-52.

37. Caputo F, Vegliante R, Ghibelli L. Redox modulation of the DNA damage response. Biochem Pharmacol. 2012; 84: 1292-1306.

38. Bartkova J, Horejsi Z, Koed K, Kramer A, Tort F, Zieger K, Guldberg P, Sehested M, Nesland JM, Lukas C, Orntoft T, Lukas J, Bartek J. DNA damage response as a candidate anti-cancer barrier in early human tumorigenesis. Nature. 2005; 434: 864-870.

39. Gorgoulis VG, Vassiliou LV, Karakaidos P, Zacharatos
P, Kotsinas A, Liloglou T, Venere M, Ditullio RA, Jr., Kastrinakis NG, Levy B, Kletsas D, Yoneta A, Herlyn M, Kittas C, Halazonetis TD. Activation of the DNA damage checkpoint and genomic instability in human precancerous lesions. Nature. 2005; 434: 907-913.

40. Bartek J, Bartkova J, Lukas J. DNA damage signalling guards against activated oncogenes and tumour progression. Oncogene. 2007; 26: 7773-7779.

41. Blagosklonny MV. Cell cycle arrest is not yet senescence, which is not just cell cycle arrest: terminology for TORdriven aging. Aging (Albany NY). 2012; 4: 159-165. doi: 10.18632/aging.100443.

42. Blagosklonny MV. Hypoxia, MTOR and autophagy: converging on senescence or quiescence. Autophagy. 2013; 9: $260-262$.

43. Carnero A. Markers of cellular senescence. Methods Mol Biol. 2013; 965: 63-81.

44. Ruiz L, Traskine M, Ferrer I, Castro E, Leal JF, Kaufman M, Carnero A. Characterization of the p53 response to oncogene-induced senescence. PLoS ONE. 2008; 3: e3230.

45. d'Adda di Fagagna F. Living on a break: cellular senescence as a DNA-damage response. Nat Rev Cancer. 2008; 8: 512522 .

46. Pospelova TV, Demidenko ZN, Bukreeva EI, Pospelov VA, Gudkov AV, Blagosklonny MV. Pseudo-DNA damage response in senescent cells. Cell Cycle. 2009; 8: 4112-4118.

47. d'Adda di Fagagna F, Reaper PM, Clay-Farrace L, Fiegler H, Carr P, Von Zglinicki T, Saretzki G, Carter NP, Jackson SP. A DNA damage checkpoint response in telomereinitiated senescence. Nature. 2003; 426: 194-198.

48. Blasco MA. Telomere length, stem cells and aging. Nat Chem Biol. 2007; 3: 640-649.

49. Blagosklonny MV. Aging: ROS or TOR. Cell Cycle. 2008; 7: 3344-3354.

50. Fumagalli M, Rossiello F, Mondello C, d'Adda di Fagagna F. Stable cellular senescence is associated with persistent DDR activation. PLoS One. 2014; 9: e110969.

51. Leontieva OV, Lenzo F, Demidenko ZN, Blagosklonny MV. Hyper-mitogenic drive coexists with mitotic incompetence in senescent cells. Cell Cycle. 2012; 11: 4642-4649.

52. Darzynkiewicz Z. When senescence masquerades as DNA damage: is DNA replication stress the culprit? Cell Cycle. 2009; 8: 3810-3811.

53. Nuciforo PG, Luise C, Capra M, Pelosi G, d'Adda di Fagagna F. Complex engagement of DNA damage response pathways in human cancer and in lung tumor progression. Carcinogenesis. 2007; 28: 2082-2088.

54. Bartkova J, Hamerlik P, Stockhausen MT, Ehrmann J, Hlobilkova A, Laursen H, Kalita O, Kolar Z, Poulsen HS, Broholm H, Lukas J, Bartek J. Replication stress and oxidative damage contribute to aberrant constitutive activation of DNA damage signalling in human gliomas. Oncogene. 2010; 29: 5095-5102. 
55. Halicka HD, Zhao H, Li J, Lee YS, Hsieh TC, Wu JM, Darzynkiewicz Z. Potential anti-aging agents suppress the level of constitutive mTOR- and DNA damage- signaling. Aging (Albany NY). 2012; 4: 952-965. doi: 10.18632/ aging. 100521.

56. Darzynkiewicz Z, Zhao H, Halicka HD, Li J, Lee YS, Hsieh $\mathrm{TC}, \mathrm{Wu}$ JM. In search of antiaging modalities: evaluation of mTOR- and ROS/DNA damage-signaling by cytometry. Cytometry A. 2014; 85: 386-399.

57. Pankotai T, Hoffbeck AS, Boumendil C, Soutoglou E. DNA damage response in the absence of DNA lesions continued. Cell Cycle. 2009; 8: 4025-4026.

58. Leontieva OV, Blagosklonny MV. DNA damaging agents and p53 do not cause senescence in quiescent cells, while consecutive re-activation of mTOR is associated with conversion to senescence. Aging (Albany NY). 2010; 2: 924-935. doi: 10.18632/aging.100265.

59. Demidenko ZN, Blagosklonny MV. Growth stimulation leads to cellular senescence when the cell cycle is blocked. Cell Cycle. 2008; 7: 3355-3361.

60. Blagosklonny MV. Calorie restriction: decelerating mTORdriven aging from cells to organisms (including humans). Cell Cycle. 2010; 9: 683-688.

61. Ferbeyre G, de Stanchina E, Lin AW, Querido E, McCurrach ME, Hannon GJ, Lowe SW. Oncogenic ras and p53 cooperate to induce cellular senescence. Mol Cell Biol. 2002; 22: 3497-3508.

62. Blagosklonny MV. Molecular damage in cancer: an argument for mTOR-driven aging. Aging (Albany NY). 2011; 3: 1130-1141. doi: 10.18632/aging.100422.
63. Demidenko ZN, Zubova SG, Bukreeva EI, Pospelov VA, Pospelova TV, Blagosklonny MV. Rapamycin decelerates cellular senescence. Cell Cycle. 2009; 8: 1888-1895.

64. Anisimov VN, Zabezhinski MA, Popovich IG, Piskunova TS, Semenchenko AV, Tyndyk ML, Yurova MN, Antoch MP, Blagosklonny MV. Rapamycin extends maximal lifespan in cancer-prone mice. Am J Pathol. 2010; 176: 2092-2097.

65. Korotchkina LG, Leontieva OV, Bukreeva EI, Demidenko $\mathrm{ZN}$, Gudkov AV, Blagosklonny MV. The choice between p53-induced senescence and quiescence is determined in part by the mTOR pathway. Aging (Albany NY). 2010; 2 : 344-352. doi: 10.18632/aging.100160.

66. Pospelova TV, Leontieva OV, Bykova TV, Zubova SG, Pospelov VA, Blagosklonny MV. Suppression of replicative senescence by rapamycin in rodent embryonic cells. Cell Cycle. 2012; 11: 2402-2407.

67. Wullschleger S, Loewith R, Hall MN. TOR signaling in growth and metabolism. Cell. 2006; 124: 471-484.

68. Sengupta S, Peterson TR, Sabatini DM. Regulation of the mTOR complex 1 pathway by nutrients, growth factors, and stress. Mol Cell. 2010; 40: 310-322.

69. Young AR, Narita M. Cell senescence as both a dynamic and a static phenotype. Methods Mol Biol. 2013; 965: 1-13.

70. Perez M, Praena-Fernandez JM, Felipe-Abrio B, LopezGarcia MA, Lucena-Cacace A, Garcia A, Lleonart M, Roncador G, Marin JJ, Carnero A. MAP17 and SGLT1 protein expression levels as prognostic markers for cervical tumor patient survival. PLoS ONE. 2013; 8: e56169. 